\title{
BEWERKING DER ALGEMEENE STATISTIEK VAN NEDERLAND.
}

\section{Het Vijfde Verslag van de Commissie van Redactie voor de bewerkiny}

eener algemenne Stratstikg van NedehLand (*), uitgebrucht door don Heer Mr. S. Visseriug, in de Vergadering van de Vereniging voor de Statistiek, gehouileu den 12n Februarij 1870, zegt o. u.

Evenals in hare vorige verslagen heeft de Commissie ook nu weder op eene lichtzijde en op eene schaduwzijde te wijzen. Aan de eene zijde op verblijdende vorderingen en voorspoed in haren arbeid; aan den anderen kant op vertraging en teleurstelling, die haar zelve niet het minst onaangenaam moesten aandoen.

In de eerste plaats een beknopt verhaal van hetgeen er in het laatstverloopen jaar verricht en tot stand gekomen is.

In het verslag van Januarij 1869 kon de Commissie er op wijzen, dat de werkzaamheden zoo verre waren gevorderd, dat men aan het drukken denken en daartoe de noodige maatregelen voorbereiden kon. Zij vroeg en verkreeg van uwe vergadering machtiging om daartoe met een Uitgever een overeenkomst aan te gaan en verder al het noodige te doen om de zak te doen welslagen. Reeds spoedig vond de Commissie gelegenheid on van deze machtiging gebruik te maken, en wel met den meest gewenschten uitslag. Tweederlei desideratum moest hierbij verwezenlijkt wordeu. Er moest in de eerste plaats een Uitgever worden gevonden, in staat en genegen om een zoo omslachtig en kostbaar werk voor zijne rekening te nemen op billijke voorwaarden. Er moesten in de tweede plaats middelen worden gevonden oin zulk een Uitgever aannemelijke voorwaarden te kunnen aanbieden. In beide opzichten was de Commissie gelukkig. De Heer A. W. Sijthoff, wiens drukkerij zulk een goeden naam in Nederland heeft, verklaarde zich bereid om de uitgave te aanvaarden, mits hem het debiet van een zeker getal exemplaren tegeu matigen prijs verzekerd wierd; en deze verzekering kon hem worden gegeven, deels door eene toezegging van het Bestuur onzer Vereeniging zelf, maar vooral door de welwillende en krachtige ondersteuning, die de Commissie mocht vinden bij de Regeering. Zoo kwam er een contract

(*) Zie het vierde verslag, Economist 1869, pag. 360 . 
tot stand, waardoor de uitgave der Algemeene Statisliek van Nederland mogeiijk is geworden. $\left({ }^{*}\right)$

Tot het sluiten dezer overeenkomst werd de Commissie (gelijk reeds gezegd is) in staat gesteld door de krachtige medewerking der Regeering.

$\mathrm{Na}$ eene correspondentie met het Ministerie van binnenlandsche zaken, die van de meeste welwillendheid van die zjjde blijke gaf, mocht de Commissie eene dispositie ontvangen d.d. 24 Maart 1869, wanrbij de Regeering verklaarde een zeker getal exemplaren voor staatsrekening te willen nemen. Uwe vergadering zal gaarne met de Commissie instemmen, wanneer zij voor deze gunstige beschikking hier dank aan de Regeering: betuigt.

Voor de plaatsing der nog overige exemplaren, voor welke de Commissie zich jegens den Heer Sijthoff verbonden had, behoefde zij geen zorg te hebben. Het Bestuur der Vereeniging oordeelde, met het oog op den stand der kas, aan de leden het aanbod te kunnen doen, om aan elk, die het mocht begeeren, een exemplaar te leveren tegen den verminderden prijs van 10 cents per vel druks. Het getal aanvragen, dat vóór den daartoe gestelden termijn in antwoord op deze aanbieding ingekomen is, was meer den roldoende om de nog overschietende exemplaren te plaatsen.

Zoo waren de bezwaren van materieelen aard tegen de mogelijkheid der uitgave overwonnen. En na eenig oponthoud, veroorzaakt doordat de noodige letters en cijfers nog niet ter drukkerij aanwezig waren, werd met het drukken begonnen.

Doch hier hebben wij nu te spreken van de schaduwzijde, waarvan in den aanvang van dit Verslag gewaagd is. Het begonnen werk is niet met dien, spoed voorgezet, welke de Commissie gewenscht en verwacht had. $\mathrm{Zij}_{\mathrm{ij}}$ had zich gevleid, dat met een geregelden en vluggen gang van het drukken een aanmerkelijk gedeelte van onze Algemeene Statistiek vór. het einde van 1869 verschenen zou zijn. In deze verwachting is zij echter teleurgesteld. Verschillende oorzaken hebben daartoe samengewerkt.

Niet gemis aan kopij, want de kopij voor Deel I ligt en lag al sedert lang gereed. Maar, behalve in andere redenen, die let hier niet noodig is te vermelden, lieeft de vertraging voornamelijk haar grond gehad in moeielijkheden en tijdverlies bij de correctie, die noodzakelijk door de auteurs zelven der verschillende bijdragen moest geschieden. Bij de correctie nu heeft zich, vooral in den laátsten tijd, door een samenloop van omstandigheden, waartegen geen ijver of aandrang op spoed iets vermocht,

(*) De financieele bijzonderheden nemen wij hier niet over; de hoofdbepaling is de straks genoemde, dat de Heer $S$. de uitgave roor zijne rekening neemt, onder roorwaarde dat hein een debiet van een zekcr getal exemplaren verzekerd worde. De prijs voor het publiek zal niet hooger mogen zijn dan 20 et. per vel druks. RED, 
velerlei stoornis opgedaan. Het gevolg is dan ook geweest, dat bij gelegenheid van het Internationaal Congres, in September te 's Gravenhage gehouden, slechts eene eerste aflevering, bevattend vel 1-7, kon worden aangeboden, en dat wij op heden nog niet verder gevorderd zijn dan tot blad 13. $\mathrm{Er}$ is echter hoop, dat deze thans bestaande hinderpalen tegen een snellen gang van het werk weldra overwonnen zullen zijn, en dat wij dan met meer spoed zullen vorderen.

Er is nog een ander bezwaar, dat wel voor 't oogenblik nog niet drukt, maar waarop toch dient gewezen te worden, omdat het ons in de toekomst dreigt te belemmeren, zoo er niet tijdig in voorzien wordt.

De kopij van Deel I ligt zooals gezegd, gereed. Ook die voor Deel II is nagenoeg voorhanden, met uitzondering van enkele der laatste hoofdstukken van dit deel. Doch van de drie overige deelen der Schets is tot nog toe weinig bij de Commissie ingekomen. $\mathrm{Nu}$ is hierbij nog wel geen hast. En zelfs is het, zooals de, ervaring reeds geleerd heeft, beter, dat sommige hoofdstukken niet al te lang voor zij ter perse gaan, afgewerkt worden, omdat daardoor de mogelijklheid word afgesneden om nieuwe belangrijke feiten, die zich tusschen de bewerking en den druk voordoen, op te nemen. Doch aan de andere zijde moet de Commissie zich het verzoek aan hare medewerkers veroorloven, dat de zaak niet in het vergeetboek kome. Het drukken mag in geen geval opgehouden worden door gebrek aan kopij. En inzonderheid bij zulke onderwerpen, die voorbereidend onderzoek eischen, is het noodig, dat men althans tijdig de bouwstoffen verzamele en niet tot de laatste oogenblikken wachte. Men zal der Commissie dezen bescheiden wenk wel ten goede houden.

Aan het slot van haar verslag heeft de Commissie nog eene mededeeling te doen, die $u$ voorzeker aangenaam zal wezen.

In haar derde Verslag (4. Januari 1868) moest zij tot haar leedwezen berichten, dat hare pogingen om van het Ministerie van financiën de bouwstoffen voor eene statistiek der hypotheken te verkrijgen ten eenemale verijdeld waren; en sommige leden dezer Vergadering zullen zich waarschijnlijk nog den inhoud herinneren van het voorgelezen schrijven van den toenmaligen Minister, waarbij alleen eenig nitzicht op vervulling van dezen wensch geopend werd, wanneer de Vereeniging voor de Statistiek eene som van p. m. $f$ 10,000 voor dit werk beschikbaar kon stellen. Het hooge belang eener statistiek der Hypotheken had inmiddels ook de andacht getrokken van de in October 1868 benoemde Rijkscommissie tot regeling van de zevende zitting van het Internationaal Congres van Statistiek. Op haar verzoek was de tegenwoordige minister van financien dadelijk bereid om zulk een Statistiek ten behoeve van haar Programma te doen vervaardigen, zoo uitvoerig als de korte beschikbare tijd zou toelaten. Het is $u$ bekend, dat deze hoogst belangrijke gegevens, die zeer de andacht der buitenlandsche bezoekers van het 
Congres getrokken hebben, opgenomen zijn in het Programma (bladz. 128 v. v.) Bij de toezending dezer Statistiek heeft de Minister tevens zijn voornemen te kennen gegeven, om dit onderwerp roor de toekomst op vasten voet te regelen. Tot uitroering van dit voornemen heeft Z.-Exc. der Commissie van Redactie de eer aangedaan, bij eene Missive van-23 April 1869 hare voorlichting te vragen omtrent de grondslagen, waarop eene deugdelijke en volledige Statistiek van het Grondcrediet zou behooren te worden aangelegd. Aan dit uitnemend blijk van belangstelling en vertrouwen heeft uwe Commissie getracht met de meeste ijver te beantwoorden. Zij heeft daartoe de hulp ingeroepen van twee leden onzer Vereeniging, die in deze als bij uitstek deskundigen mogen worden aangemerkt. De gevraagde hulp is haar met de meeste bereidwilligheid verleend, en bij Missive van 15 Juli 1869 heeft de Commissie Verslag van haar onderzoek aan den Minister kunnen inleveren.

Zonder twijfel zal uwe vergadering instemmen met de dankbetuiging, die de Commissie hier wenscht aan te bieden aan Z.Exc. den Minister van financiën voor de waardeering van ons streven, waarvan zijne vereerende opdracht blijk gaf, en aan de twee leden onzer Vereeniging, de Heeren Ph. J. Bachiene en Mr. Walrave van Heukelom, die als deskundigen door hunne medewerking ons in staat gesteld hebben de opdracht des Ministers waardiglijk te vervullen. 


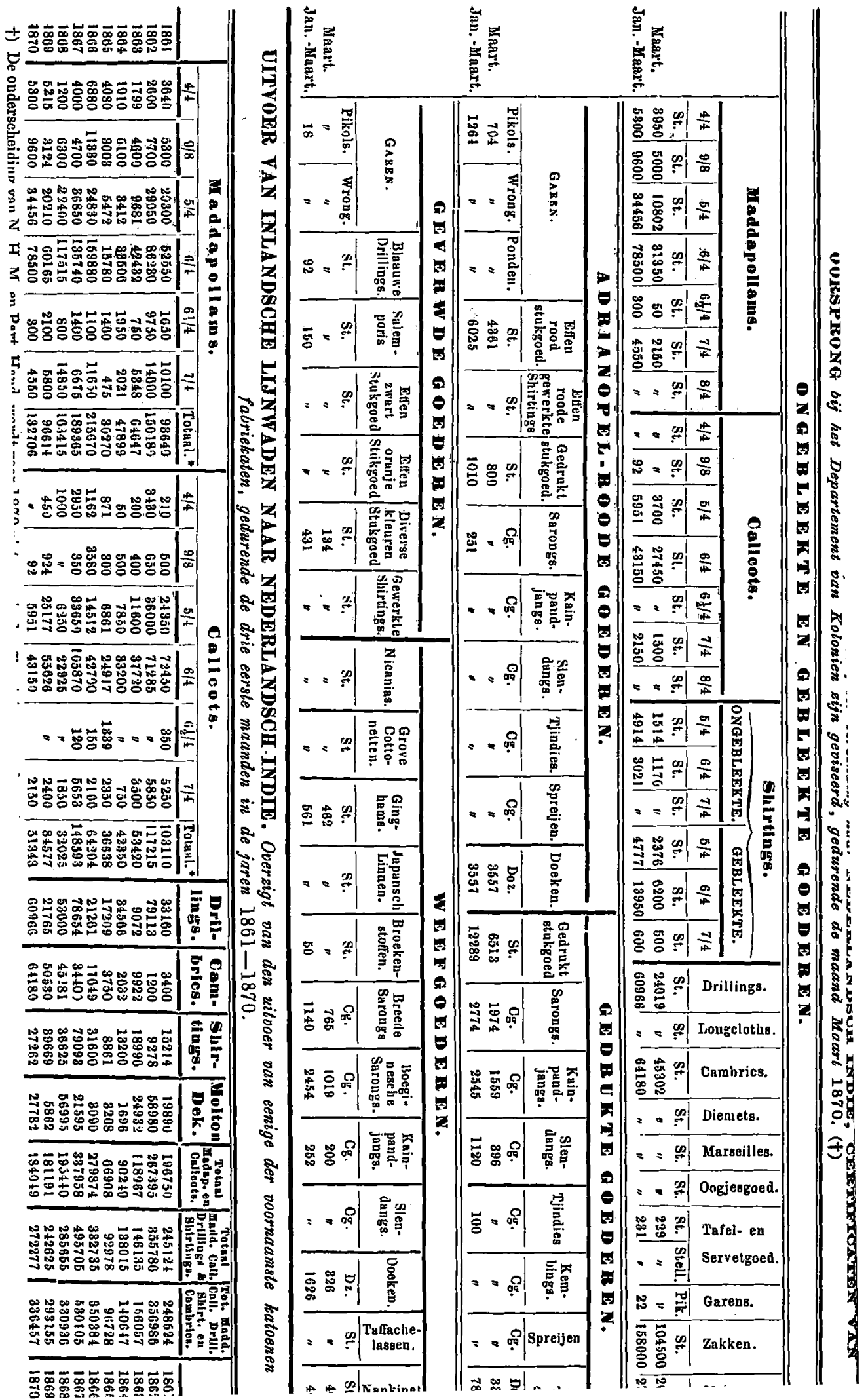



aan de Beurs te Amsterdam.

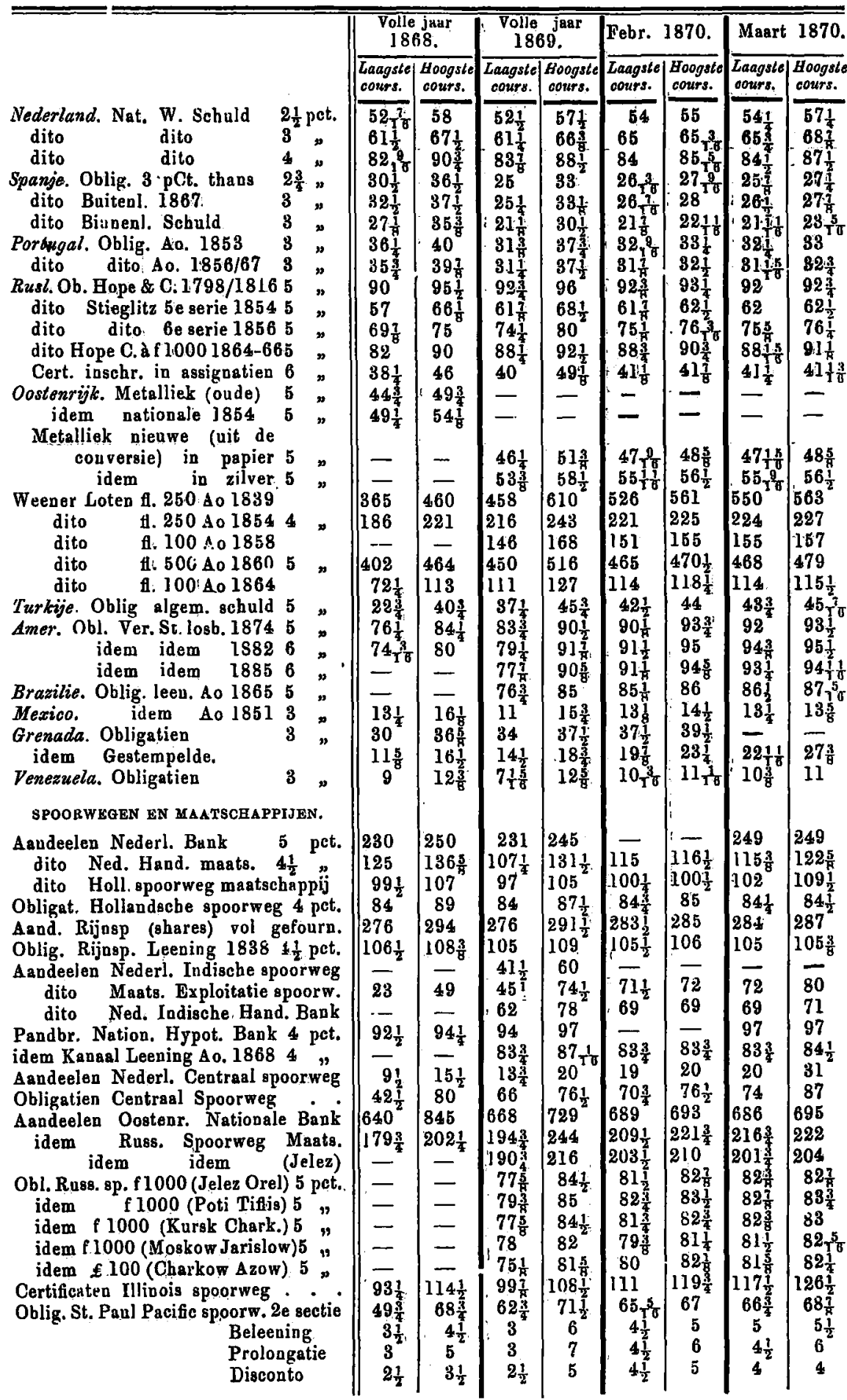


NEDERIA N D C HE B A N R.

(In millioentallen guldens.)

\begin{tabular}{|c|c|c|c|c|c|c|c|c|c|c|}
\hline DATOK： & $\begin{array}{c}\text { Discon- } \\
\text { to's. }\end{array}$ & $\begin{array}{c}\text { Bolee- } \\
\text { ningon. }\end{array}$ & $\begin{array}{c}\text { Oper. } \\
\text { kapitaa! }\end{array}$ & $\begin{array}{c}\text { Bank- } \\
\text { billetten. }\end{array}$ & $\begin{array}{l}\text { Saldo's } \\
\text { rek. crt. }\end{array}$ & $\begin{array}{l}\text { Munt- } \\
\text { yoorraud. }\end{array}$ & $\begin{array}{c}\text { Voorrazd } \\
\text { billet. }\end{array}$ & $\begin{array}{c}\text { Surplus } \\
\text { dekking. }\end{array}$ & $\begin{array}{c}\text { Wissel- } \\
\text { disconto. }\end{array}$ & $\begin{array}{l}\text { Prolon } \\
\text { koers }\end{array}$ \\
\hline 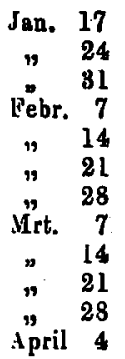 & $\begin{array}{l}61.43 \\
58.73 \\
58.69 \\
57.42 \\
55.88 \\
54.12 \\
52.61 \\
51.15 \\
51.47 \\
51.49 \\
50.55 \\
50.78\end{array}$ & $\begin{array}{l}36.90 \\
35.70 \\
35.83 \\
34.36 \\
33.55 \\
33.23 \\
32.96 \\
32.95 \\
32.97 \\
32.93 \\
32.87 \\
32.58\end{array}$ & $\begin{array}{l}97.33 \\
94.43 \\
93.52 \\
91.78 \\
89.43 \\
87.35 \\
85.57 \\
84.10 \\
84.44 \\
84.42 \\
83.42 \\
83.36\end{array}$ & $\begin{array}{l}136.07 \\
135.11 \\
133.13 \\
131.84 \\
129.21 \\
127.62 \\
126.23 \\
125.78 \\
126.81 \\
126.57 \\
125.92 \\
127.24\end{array}$ & $\begin{array}{l}23.71 \\
28.04 \\
24.54 \\
24.33 \\
25.08 \\
24.75 \\
25.03 \\
24.23 \\
24.81 \\
24.61 \\
25.08 \\
23.49\end{array}$ & $\begin{array}{l}81.16 \\
82.48 \\
83.03 \\
83.34 \\
83.88 \\
84.12 \\
84.86 \\
85.18 \\
86.05 \\
86.20 \\
87.08 \\
86.88\end{array}$ & $\begin{array}{l}43.12 \\
48.05 \\
49.90 \\
52.18 \\
55.41 \\
57.93 \\
60.89 \\
62.94 \\
64 .- \\
64.32 \\
66.70 \\
66.47\end{array}$ & $\begin{array}{l}17.25 \\
19.22 \\
19.96 \\
20.87 \\
22.16 \\
23.17 \\
24.36 \\
25.18 \\
25.60 \\
25.73 \\
26.68 \\
26.59\end{array}$ & $\begin{array}{l}5 \text { (3 Nor.) } \\
" \\
\Rightarrow \\
4 \frac{1}{2}(15 \text { Feb.) } \\
4(28 \text { Feb.) } \\
" \\
\Rightarrow \\
=\end{array}$ & $\begin{array}{l}5 \\
43 \\
5 \frac{1}{2} \\
6 \\
5 \frac{1}{2} \\
5 \\
37 \\
6 \\
5 \frac{1}{2} \\
5 \\
4 \frac{3}{4} \\
5\end{array}$ \\
\hline
\end{tabular}

WISSELKOERSEN TE AMS'TERDAM.

\begin{tabular}{|c|c|c|c|c|c|c|c|c|c|c|c|c|c|c|c|}
\hline DATUM. & $\begin{array}{c}\text { kort } \\
\text { Londen. }\end{array}$ & $\begin{array}{c}\text { kort } \\
\text { Parijs. }\end{array}$ & $\begin{array}{c}\text { kort } \\
\text { Haumb. }\end{array}$ & $\begin{array}{c}\text { Frankf. } \\
6 / w .\end{array}$ & DATUM. & 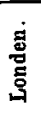 & 总 & 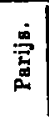 & 窎 & 离 & 怤 & 总 & 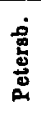 & 急 & $\begin{array}{l}\dot{\vec{\Xi}} \\
\dot{m} \mathbf{m}^{2} \\
\dot{m}\end{array}$ \\
\hline 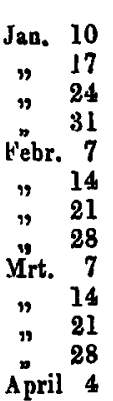 & \begin{tabular}{l}
11.83 \\
11.84 \\
11.90 \\
11.89 \\
$11.89 \frac{1}{2}$ \\
11.89 \\
11.91 \\
11.89 \\
$11.89 \frac{1}{2}$ \\
11.90 \\
\multicolumn{1}{c}{}
\end{tabular} & 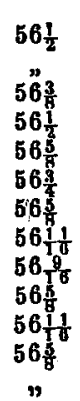 & 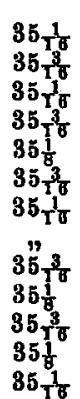 & $\begin{array}{c}98 \frac{1}{2} \\
98 \frac{1}{4} \\
" \\
" \\
" \\
98 \frac{1}{2} \\
" \\
" \\
" \\
" \\
"\end{array}$ & $\begin{array}{rr}\text { Jan. } & 8 \\
" & 15 \\
" & 22 \\
" & 29 \\
\text { Febr. } & 5 \\
" & 12 \\
" & 19 \\
" & 26 \\
\text { Mrt. } & 5 \\
" & 12 \\
" & 19 \\
" & 26 \\
\text { Dpril } & 2\end{array}$ & $\begin{array}{l}\text { 3 } \\
\text { " } \\
" \\
" \\
", \\
" \text { " } \\
\text { " }\end{array}$ & $\begin{array}{l}5 \\
" 1 \\
" \\
" 1 \\
4 \frac{1}{2} \\
4 \\
4 \\
"\end{array}$ & $\begin{array}{l}2 \frac{1}{2} \\
" \\
" \\
" \\
" \\
" \\
" \\
" \\
" \\
"\end{array}$ & $\begin{array}{l}5 \\
" \\
" \\
" \\
4 \\
" \\
" \\
"\end{array}$ & $\begin{array}{l}4 \\
" \\
" \\
" \\
" \\
3 \frac{1}{2} \\
" \\
" 4 \\
"\end{array}$ & $\begin{array}{l}5 \\
" \\
" \\
" \\
" \\
" \\
" \\
" \\
" \\
"\end{array}$ & $\begin{array}{l}5 \\
" \\
" \\
" \\
" \\
" \\
" \\
" \\
" \\
" \\
"\end{array}$ & $\begin{array}{l}6 \\
" 5 \\
" 1 \\
" \\
" \\
" \\
" \\
" \\
"\end{array}$ & $\begin{array}{l}\text { " } \\
" 1 \\
" \\
" \\
" \\
" \\
" \\
"\end{array}$ & $\begin{array}{l}2 \frac{1}{2} \\
" \\
" \\
" \\
" \\
" \\
" \\
" \\
" \\
"\end{array}$ \\
\hline
\end{tabular}

GNGELAND'S IN. EN UITVOEREN VAN EDELE METALEN.

\begin{tabular}{|c|c|c|c|c|c|c|c|}
\hline \multirow{2}{*}{\multicolumn{2}{|c|}{$\begin{array}{l}\text { In de week } \\
\text { eindigende: }\end{array}$}} & \multicolumn{3}{|c|}{ INTOEE VAN GOUD EN ZILVER. } & \multicolumn{3}{|c|}{ UTTVOER VAN GOUD EN ZILVER. } \\
\hline & & Goud. & Zilver. & Totaal. & Goud. & Zilver. & Totaal. \\
\hline $\begin{array}{l}\text { Jan. } \\
\text { Febr. } \\
\text { " } \\
\text { Maart } \\
" \\
" \\
" \\
"\end{array}$ & $\begin{array}{r}19 \\
26 \\
2 \\
9 \\
16 \\
23 \\
2 \\
9 \\
16 \\
23 \\
30\end{array}$ & $\begin{array}{r}\text { pd. st. } \\
85.938 \\
6.957 \\
429.089 \\
115.708 \\
62.542 \\
52.126 \\
441.920 \\
38.907 \\
11.336 \\
118.040 \\
439.353\end{array}$ & $\begin{array}{r}97.708 \\
14.392 \\
326.785 \\
251.296 \\
116.552 \\
113.116 \\
239.685 \\
6.980 \\
51.605 \\
106.881 \\
97.592\end{array}$ & $\begin{array}{r}183.646 \\
21.349 \\
755.874 \\
367.004 \\
179.094 \\
165.242 \\
681.605 \\
45.887 \\
62.941 \\
224.921 \\
536.945\end{array}$ & $\begin{array}{r}\text { pd. st. } \\
233.737 \\
144.791 \\
275.209 \\
105.676 \\
58.059 \\
46.613 \\
69.125 \\
7.376 \\
34.012 \\
106.288 \\
75.199\end{array}$ & $\begin{array}{r}97.708 \\
58.059 \\
20.251 \\
237.769 \\
171.224 \\
188.419 \\
86.339 \\
195.884 \\
94.398 \\
139.886 \\
157.553\end{array}$ & $\begin{array}{l}331.445 \\
202.850 \\
295.460 \\
343.445 \\
224.283 \\
230.532 \\
155.464 \\
203.260 \\
128.410 \\
246.174 \\
232.752\end{array}$ \\
\hline
\end{tabular}




\section{ECONOMISGHE NALEZINGEN EN BERIGTEN.}

Het. verslag over 1869 der Amsterdamsehe Crediet-Vereeniging, uitgebracht in de Algemeene vergadering gehouden op 5 April 11., toont wederom de goede réussite dier onderneming die wij vroeger meermalen bespraken. (*)

Belooft de deelneming interest? - zegt de $N$. Rott. Ct. Zeker een iets hooger pCt. dan 't kapitaal belegd in eenig solied staatspapier b. v. onze nat. schuld. De Credietvereeniging gaf $7 \frac{1}{2}$ pCt. over 1864, 8 over $65,8 \frac{1}{2}-7 \frac{1}{4}-7$ pCt. over $68,7 \frac{1}{4}$ over 1869 , d. i. gemiddeld ruim $7 \frac{1}{2}$ pCt. over de laatste zes jaar, een tijd van een juist niet zeer opgewekt handelsverkeer!

Men wordt lid tegen betaling van 't nominaal bedrag van zijn aandeel, alleen vermeerderd met een zekere bijdrage tot 't reservefonds. Men stort op dat bedrag van zijn aandeel naar verkiezing : minstens $f 50$, en hoogstens f 30,000 ; ieder aandeel van f 300 gestort, geeft stem; ieder lid heeft slechts één stem; hoe groot 't bedrag zijner deelneming zij.

De Vereeniging opent krediet voor haar leden; zij laat aan ieder die hiervan gebruik maakt, vrijheid tot opzegging van zijn lidmaatschap ten allen tijde. Zij beperkt voor deze 't dividend tot $1 \frac{1}{2} \mathrm{pCt}$. beneden 't cijfer voor de "niet-krediet-trekkende" leden-aandeelhouders. Een onderling krediet - versterkt door den steun dier commanditaire medeleden-aandeelhouders.

Zij geeft krediet aan ieder wie als krediettrekkend lid wordt aangenomen, tot 't volle bedrag zijner deelneming, in blanco, op hypotheek, op borgtocht, en voor een klein deel in cassa's. Zij geeft op haar beurt het daarvoor ontrangen papier in disconto bij anderen (o. a. bij de Nederlandsche bank), neemt kassiersdiensten waar, en ontvangt gelden in deposito tegen vergoeding van rente. Het voordeel van deelneming is dus, dat men voor 't tienvoud zijner storting, desverlangd, krediet in blanco erlangt, en deelt in de winsten der onderneming.

't Getal leden (krediet- en niet-krediettrekkende) was op den 31sten December: 1869: 2360; - op den 31 December 1853 (jaar van oprichting): 197 ; 't maatschappelijk kapitaal: $f 14 \frac{1}{4} \mathrm{~m}$., en $f 1 \mathrm{~m}$; gestort $f \frac{3}{4}$., en $\frac{1}{4} \mathrm{~m}$. 't Getal aandeelhouders nam steeds toe; dat der krediettrekkende leden daalde over de laatste jaren; - waar overigens beide verspreid wonen, wordt niet meer opgegeven. Vooral een strenger toezicht, met name op 't voortdurend prolongeeren van eenmaal aangenomen

(*) Zie b. จ. Econ. 1857 , p. 203 ; 1859 , p. 225 ; 1860 , p. 228 . Bijbl. 1861 p. 197. 
accepten, en voorts en vooral aflossing en executie van hypotheek op minwaardige en achteruitgaande panden, bewerkten die daling, in 't belang der Vereeniging zelve, die in beide gevallen 't gevaar droeg. Een disconto werd berekend (plns $\frac{1}{8} \mathrm{pCt}$. provisie) van $4 \frac{1}{2} \mathrm{pCt}$. bij 't begin, tot $7 \mathrm{pCt}$. (voor le hypotheek $\frac{1}{2}$ pCt. lager) bij 't einde van 't jaar; een deposito uitgekeerd van $\frac{1}{2}$ tot $4 \frac{1}{2}$ pCt. Het eerste (in den regel op papier van $3 / \mathrm{m}$.); op eene totale waarde van ruim $f 34$ mill. ; bij hypothecair krediet geldt daarbij, gelijk bekend , 't gemak eener krediet-hypotheek, d. i. van eene doorloopende inschrijving voor een waarde die eerst later bij vereffening in saldo wordt aangenomen. Het laatste (één dag na aanvraag beschikbaar) tot een waarde van ruim $10_{\frac{1}{2}} \mathrm{~m}$., een hooger cijfer dan over eenig jaar. - Hoe groot, of hoe klein die disconto's en deposito's waren, voor hoe lang ze liepen, wien ze dienden, den grooten of kleinen man - wordt in 't verslag niet medegedeeld. Wel, het verlies aan dezen en genen geleden, deels bij faillissement of opgehouden betaling: bijna $\frac{1}{2}$ pCt. $(0,47)$ van het totaal der deelneming van krediettrekkende leden, of ruim $0,18 \mathrm{pCt}$. van 't totaal verleend krediet; een verlies, dat we met de Directie hopen bij een strenger toezicht in 't vervolg te zien dalen. De zuivere winst bedroeg $f 115.000$

Zuivering van drinkwater. Eene gemakkelijk aan te wenden en zeer weinig kostbare wijze om onzuiver putwater, rivierwater of vaartwater te zuiveren van de organische, voor de gezondheid zeer nadeelige bestanddeelen, waarmede het veelal verontreinigd is, is de volgende:

Men doet het water in een ton of houten emmer, en vermengt er mede eene oplossing van chloretum ferricum, waarvoor het best te gebruiken is de liquor stypticus, in elke apotheek voorhanden.

Op elke 10 kannen water (een kleine emmer vol) wordt van dat vocht eene hoeveelheid van $\stackrel{9}{\text { go }}$ gram (ongeveer 14 grein) gedaan. Het water wordt dan goed omgeroerd en 24 uren in rust gelaten. $\mathrm{Na}$ dien tijd vindt men het water geklaard, en op den bodem een dik bezinksel. Men schenkt nu hẹt wațer voorzichtig van het bezinksel af, of giet het door een doek. Is het dan volkomen helder, kleurloos en zonder zuren of ziltigen smaak, dan kan het met gerustheid als drinkwater worden gebezigd.

Mogt het water eenigzins samentrekkend (inktachtig) smaken, dan kan dit geen kwaad, maar bewijst dat men een weinig te veel liquor stypticus heeft gebruikt.

Toen bij de aanhoudende droogte van 1868 in Noord-Holland zeer groot gebrek was aan zuiver drinkwater, heeft de geneeskundige inspecteur voor Noord-Holland deze wijze van waterzuivering medegedeeld aan den Commissaris des Konings in die provincie, en heeft deze haar in een Provinciagal Blad ter kennis van de gemeente-besturen gebrachț. Injerschillende gemeenten is dan ook van die wijze van zuivering zexpel 
en n'et nitstekend gevolg gebruik gemaakt; zelifs slootwater is daardoor tot drank geschikt gemaakt geworden.

Flet 'spreekt van zelf, dat deze mèthode nièt anleèn aanwìndbar is en a'anprijzing vcrdiẹnt in tijd'en vain watèrgebrek, maar ook overtal èn altijd waar en wanneer twen niet dan onzuiver watter ter zijner beschikking heeft. Het gebruik van onzuiver water nu is zó6 nadeelig (niets bevordert o. a. ineer dan dit het ortstatan van Typhus, Cholera, 'enz.), dat ik g'trineend hèb de aandacht van het publiek op deze zuiveringswijze te moeten vestigen.

Dr. LOBACH.

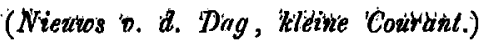

- Be Rotterdamstre ámbächitisschool, werd den 1lèn Apiril 1l. , in tegentoordighierd van den Minister $\forall$. Binn. Zaken 'en vele andere aútoriteiten op plegtige wijze geopend. Het eerste denkbeeld tot oprigting dezer 'school is in 1864 vain de Rott. Afd. der maatscluappif t. bet. t. Bouwk kunst uitgegaan "en, na overleg thet eentge andere Gen'ootschappen, teh slotte door haar nitgevoèd. De kosten wordèn door giften en jabrlijksche inschrijvingen, en ook door een gem'éntesubsidie van $f 6000$ gédekt. De N.-R. Ct. geeft èene korte beschrijuring tan het gebobuw (ain de Hofdijk).

Op deh beganen grotid heêft men de woning van den directétur en đê bestuurders-kamer, benevens 'eene lées- eh eetie conversatiezaal, foor de

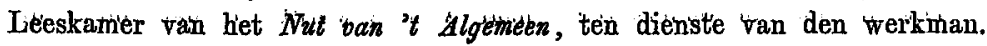

In het benedengeboutw vindt inen de werkplatatsen voor de bedirijutin van metselaars, steenhouwers en boetseerders, met de noodige bergplaatsen voor inaterialen, enz.

Op de eerste bovenverdieping komt men in twee léerlokalèn voor herlialings-onderwijs en onderricht in dé wis- en natuurkandige wetènschappen; voorts zijn aldaar de directeurs-kamer, twee groote téekenlokkalen en èene kamer voor de onderwijzers tijdens de rust tusschen de lessen.

Op de daarop volgende verdieping is de groote teekènzaal (latig 20 breed 6 mèters) en zijn twee lokal'en voorloopig ingericht tot onderwijs in hand- en ornamènt-teèkenèn, alsook tot hèt teékenen naar voor'werpen in de ruimte. Verder zijn ook aldaar de noo dige bergiplaátsen voor materialen, geteedschappen enz. en eene wachtkamer voor onderwijzer's.

Op de derde verdieping is 'énê kolossäle ruimite voor vërdere uitbreiding beschikbaar. Voorloopig wordt daar naast eene huisschildèrts-werkplaats gereed gemaakt.

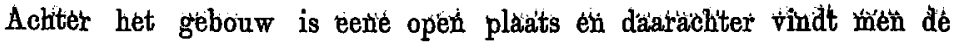
volgende werkplaatsen; le voör blik-, kopér-, èn ànder metälwèrk, mĕt smidse en forceerbank; 2e voor smedèrij (vuiurwerk); 3’è voór símids-, bank- en draaiwerk; 4e voor het timmermansvak. Boven deze werkplaatsen 
is het lokaal voor de werkzaamheden van het houtdraaiers-, het beeldhouwers- en het schrijnwerkersbedrijf.

Behalve voor de genoemde vakken zijn er ook leerlingen aangenomen voor het steendrukken, boekdrukken en letterzetten. Deze leerlingen zullen echter eerst nog het voorbereidend onderwijs genieten.

Is het eene lichte taak om in enkele trekken de inrichting van het gebouw te beschrijven, het is onmogelijk den weldadigen indruk weêr te geven, dien zij op den bezoeker maakt. Ieder moet bij het beschouwen van die ruime, luchtige, rriendelijke lokalen, waarin alles gereed staat wat voor theoretisch en practisch onderwijs noodig kan zijn, tot de overtuiging komen dat de sprekers volkomen gelijk hadden, toen zij er op wezen dat de Ambachtschool geroepen is om oneindig veel bij te dragen tot verbetering der toekomst van den ambachtsman. De leerlingen kunnen er al hun tijd wijden aan het onderwijs, hetgeen, indien zij dadelijk als leerjongens bij bazen in dienst treden, geenszins het geval is. Dat onderwijs wordt hun in de Ambachtsschool meer regelmatig en meer stelselmatig toebedeeld dan in particuliere werkplaatsen doenlijk is. De lokaliteiten, waarin het onderwijs wordt verstrekt, zijn geschikter en gezonder dan die waarover menige baas beschikken kan. Het practisch onderwijs gaat bovendien gepaard met onderricht in de theorie. Op die wijze zal men weldra een nieuw ras van ambachtslieden zien optreden, die, dank zij hunne kennis en beschaving, eene toekomst te gemoet gaan, welke voor den minder ontwikkelde werkman geheel onbereikbaar is. Dat dit door de ouders reeds naar waarde wordt geschat, blijkt uit let aantal jongelieden, waarmede de school is geopend.

- Volksgymnastiek. Het departement Sneek $t$. $N$. v. ' $\ell$ Alg. besprak in hare vergadering van 13 April een zeer belangrijk stuk nl. de oprichting eener Volksgymnastiekschool. Sedert 1861 bestaat te Sneek eene instelling voor gymnastiek, grootendeels gesticht door vrijwillige bijdragen der leden. $\mathrm{Na}$ negen jaren tijds zijn al de schulden, die de inrichting drukten, afgelost en zal zij beginmen een winstgevende te worden. Dit heeft het bestuur op het uitmuntend denkbeeld gebracht naast de bestaande eene tweede te stichten, uitsluitend voor het volk. Men heeft gemeend, dat het vooroordeel tegen zulk eene school wel zou te overwinnen zijn en het volk spoedig zou beginnen in te zien, dat het tot zijn eigen welzijn en dat zijner kinderen zou strekken, wanneer de gelegenheid voor zulk onderwijs werd geopend. Daarom werd aan de leden voorgesteld de noodige stappen te doen zulk eene inrichting in het leven te roepen en de meerderheid besliste in den geest van het ingediende rapport. Wij hopen dat in dezen de noodige steun zal worden verleend en kunnen van de beoogde instelling niets anders dan goeds verwachten. $\quad$ N. $R$. C. 